\title{
Zihinsel Yetersizliği Olan Çocuklar ve Oyun Ortamında Akran Etkileşimi
}

\author{
Doç. Dr. Arzu ÖZYÜREK* \\ Karabük Üniversitesi, Sağlık Bilimleri Fakültesi, Çocuk Gelişimi Bölümü, Karabük / Türkiye
}

Bilm. Uzm. Ayşenur SAKA

Millî Eğitim Bakanlığı, Çelik İş Ortaokulu, Psikolojik Danışman, Karabük / Türkiye

\section{$\ddot{O} z$}

Bu çalışmada, hafif zihinsel yetersizliği olan bir çocuğun tek başına ve normal gelişim gösteren ve zihinsel yetersizliği olan akranları ile etkileşim halinde iken tercih ettiği oyun davranışlarını değerlendirmek amaçlanmıştır. Çalışmada nitel araştırma deseni kullanılmış, bir kişinin davranışı hakkında detaylı bilgi vermeye yönelik vak’a çalışması yapılmıştır. Veriler gözlem metoduyla elde edilmiştir. Çalışma grubunu 11 yaşındaki zihinsel yetersizliği olan 1 çocuk ile akran etkileşiminin görülebilmesi için 2 normal gelişim gösteren ( 1 kız, 1 erkek) ve 2 zihinsel yetersizliğe sâhip akranı (1 kız, 1 erkek) oluşturmuştur. Gözlem sonuçları için içerik analizi yapılmış ve elde edilen bulgular temalar hâlinde sunulmuştur. Sonuç olarak, hafif zihinsel yetersizliği olan çocuk tarafından oyun merkezi olarak daha çok blok merkezinin tercih edildiği görülmüştür. Sosyal oyun davranışı olarak birlikte oyun oynama davranışı görülmüş, çocuğun kız veya erkek ayrımı olmaksızın akranları ile etkileşimde bulunmayı tercih * Sorumlu Yazar. Tel: +90 $5303632633 \quad$ E-posta: a.ozyurek@karabuk.edu.tr $\quad$ ORCID: 0000-0002-3083-7202 (C) 2017 Kalem Eğitim ve Sağlık Hizmetleri Vakfı. Bütün Hakları Saklıdır. ISSN: 2146-5606 
ettiği ve bu etkileşimin onu mutlu ettiği belirlenmiştir. Alanyazın ve bulgular ışığında, yetersizliğe sâhip çocukların oyun ortamında akranları ile etkileşiminin gelişimsel açıdan önemi tartışılmıştır.

Anahtar Kelimeler: Zihinsel yetersizlik; Oyun; Akran etkileşimi.

\title{
Mentally Retarded Children and Peer Interactions in the Game Environment
}

\begin{abstract}
The aim of this study is to evaluate game behaviors of a child with mild mental disability either alone or during the interaction with peers with normal development as well as peers with mental disabilities. In this qualitative study, case study was performed in order to provide detailed information related to the behavior of an individual. Data were collected via observation technique. The experimental group was composed of one child with mental disability who was 11 years old, 2 children with normal development ( 1 female and 1 male) and 2 children with mental disability ( 1 female and 1 male) in order to observe the peer interaction. The content analysis was performed for the observational data and findings were presented as themes. As a conclusion, we observed that the child with mild mental disability preferred mostly the block center as a game center. The child exhibited a playing behavior together with peers without differentiating the gender and we observed that the child was happy due to the peer interaction. In literature, the importance of the peer interaction of children with disabilities in the game environment has been broadly discussed.
\end{abstract}

Keywords: Mental disability; Game; Peer interaction.

\section{Extended Summary}

\section{Purpose}

Game is the most important activity which prepares a child to the life. Game entertains children and they realize their powers and skills, recognize the environment and objects around them, becomes aware of their distinctive features compared to others, recognize themselves and reveal their feelings by playing games. With the help of games, children learn a lot of things from 
adults, their peers as well as from older children who are more experienced in life. Game is very important either for children with normal development or children with special needs. However, children with disabilities develop slower compared to children with normal development. Therefore, we should consider the developmental levels of these children rather that their ages while assessing their game behaviors. Game facilitates the physical development of children with mental disability. Games which provide them to interact with others lead them to be more social in society. In this way, they gain both self-confidence feeling and trust for the environment. Their behavioral competencies and cognitive skills increase. In literature, there are limited numbers of studies related to the examination of game behaviors of children with mental disability or normal development.

The aim of this study is to evaluate game behaviors of a child with mild mental disability either alone or during the interaction with peers with normal development as well as peers with mental disabilities.

\section{Method}

This study was carried out using relational survey model. Accordingly, structural equation model was used to determine the relationships between motivation and the level of perceived social support.

In this qualitative study, case study was performed in order to provide detailed information related to the behavior of an individual. A male child with mental disability was the case of our study. He was named 'Ali' throughout the study. In order to observe the peer interaction of Ali, two children with normal development (one female and one male) and two children with mental disability (one female and one male) were included in this study. Data were collected by using observation method. In order to examine the game behavior of Ali, researchers observed his game behaviors when he was alone in the classroom (two observations), when he was with female and male peers with mental disability (two observations), when he was with female and male peers with normal development (two observations), when he was with female peers with normal development and with a mental disability (two observations), when he was with male peers with normal development and with a mental disability (two observations), and when he was with all of his peers (two observations). The results of observations were evaluated with content 
analysis and findings were presented as themes.

\section{Results}

According to our findings related to game behaviors of Ali in terms of his peer interaction, we observed that he preferred to play with his friends in the block and dramatic game centers and he was isolated for a short time when he was with only one peer. Ali preferred to play together with his peers with normal development and they used mostly the block and dramatic game center and classroom game area. In terms of the preference, Ali preferred to play with his male peers. When he was with his peers, he exhibited isolated game behavior for only 1 to 3 minutes.

When we examined game behaviors of Ali in terms of his peer interaction and his mood while he was playing alone, we observed that he was wandering aimlessly in the classroom, he had difficulty to build games and he was not happy. Besides, when he was playing with his peers, he was happy and he was even happier as the number of peers increased. It was observed that Ali preferred to play with his peers, wanted to interact with other children and he was actually interacting with them. Furthermore, we also observed that he did not make gender discrimination, he joined the game of others, he invited others who were out of the game and he obeyed the rules of the game.

\section{Discussion and Conclusion}

Peer interaction supports not only social development of children but also their language development, emotional development and mental development including concept learning. This interaction can be mostly provided during games. With the help of these game opportunities, children with disabilities learn to interact with others, develop friendships and work with other individuals. According to literature, children with mental disabilities also need to interact with peers as other children with normal development. Therefore, it is important to mention that interaction with peers will support the development of children with disabilities and this interaction will also contribute to the social abilities of children with normal development.

\section{Giriş}

Nerede ve hangi zaman diliminde olursa olsun, çocukların tek isteği “oyun oynamak”tır (Ormanlığlu-Uluğ ve Karadeniz, 2011). Oyun, amaçlı ya 
da amaçsız, kurallı ya da kuralsız gerçekleştirilebilen, çocuğun isteyerek ve hoşlanarak boş zamanlarında ya da kısa bir zaman aralığında yaptığı eylemlerdir (Adıgüzel, 2013; Aydın, 2012). Oyun, çocuğu hayata hazırlayan bir faaliyettir (Aydın, 2004). Çocukların duygularını ifade etmeleri, enerjilerini boşaltmaları, sosyal beceri davranışlarını geliştirmeleri, problem çözme yetisini kazanmaları, başkalarının duygularını ve kendi sınırlıklarını anlama, alışkanlık ve deneyim kazanmaları, diğer bireylerle sağlıklı iletişim kurmayı kendi kendilerine öğrenmeleri için oyun oynamaları gerekmektedir (Aydın, 2012; Çelebi-Öncü ve Özbay, 2006; Gülay ve Akman, 2009; Pellegrini, 2009; $\mathrm{Xu}, 2010)$.

Piaget'e göre oyun, çocuğun bilişsel gelişimini destekler (MEB, 2009). Piaget, çocuğun oyun gelişiminde kendi aktivitesi ve yakın çevresine vurgu yaparken Vygotsky ve Winnicott sosyal etkileşimlerine vurgu yapmaktadırlar (Brodin, 1999). Erik Erikson'a göre çocuk, gerçekleştirilmez hayalî arzularının farkına varır ve bunları oyun sayesinde hayalî düzeyde yürütür (Hirsh, 2004). Hayalî oyunlar, sosyal olgunluğa ve bilginin inşasına katkıda bulunur (Fox ve Schirrmacher, 2014). Oyun çocuğun fiziksel, zihinsel, duygusal, sosyal, dil ve motor becerilerinin gelişimini, yaratıcılık ve problem çözme becerilerinin gelişimi ve kişilik gelişimi üzerinde önemli bir etkiye sâhiptir (Ar1, 2006; Javan, Abedi, Nattaj ve Dehghani, 2012; Ormanlığlu-Uluğ ve Karadeniz, 2011). Oyun, çocuğun en önemli işidir. Çocuk oyun oynarken sadece eğlenme amacı gütmez, aynı zamanda oyun ortamında gücünü ve yeteneğini dener, içinde yaşadığı çevreyi ve eşyayı keşfeder, kendisini başkalarından ayıran özelliklerin farkına varır, duygularını açığa vurur (Çankırılı, 2010). Çocuklar oyun sayesinde yetişkinlerden, yaş olarak büyük deneyimli çocuklardan veya akranlarından birçok şey öğrenmektedirler (Veer, 1996). Bandura'nın sosyal öğrenme kuramına göre çocuklar pek çok davranışı gözleyerek öğrenirler (Arı, 2006). Vygotsky'e göre ise, oyunda yer alan sembolik durumlar kültürü yansıtmakta ve bu sayede çocuk kuralları, sosyal becerileri ve iletişimi dişardan bir zorlama olmadan, kendiliğinden öğrenmektedir (Çeçen, 2007).

Oyun, normal gelişim gösteren çocuklar için ne kadar önemliyse, özel gereksinimli olan çocuklar için de o derece gereklidir. Yetersizliği olan çocukların bilişsel ve çevresel faktörleri, normal gelişim gösteren çocuklardan genellikle farklıdır (Brodin, 1999). Zihinsel işlevler bakımından ortalamanın 
iki standart sapma altında farklılık gösteren, buna bağlı olarak kavramsal, sosyal ve pratik uyum becerilerinde eksikleri ya da sınırlılıkları olan ve özel eğitim hizmetlerine ihtiyaç duyan bireyler, zihinsel yetersizliği olan bireylerdir (MEB, 2011; Özel Eğitim Hizmetleri Yönetmeliği, 2006; Swith, 2013). Özel gereksinimli olarak ele alınan zihinsel yetersizliğe sâhip çocukların gelişimi için de oyun önemli bir unsurdur. Ancak özel gereksinimli çocuklar, normal gelişim gösteren çocuklara oranla daha yavaş gelişim göstermektedirler. Bu nedenle, bu çocukların oyun davranışları değerlendirilirken içinde bulundukları yaşın özelliğinden ziyade gelişimsel düzeyleri dikkate alınma1ıdır (Çelebi-Öncü ve Özbay, 2006).

Zihinsel yetersizliğe sâhip çocukların bağımsız davranışlar sergileyebilmeleri, onlara gerekli beceri ve davranışları kazandırabilecek eğitim etkinlikleri ile sağlanabilir. Özellikle erken yaşlarda, zihinsel yetersizliğe sâhip çocuklara oyun firsatları sunulması, onların bütün gelişimlerini olumlu ölçüde etkileyecektir (Sevinç, 2004). Zihinsel yetersizliği olan çocuklar, oyun esnasında kendi bedenini ve başkalarının bedenlerini fark eder. Oyun, zihinsel yetersizliği olan çocuğun beden gelişimine yardımcı olur. Çevre ile işbirliğini geliştirecek oyunları oynamaları, daha sosyal olmalarını sağlar. Hem kendilerine hem de çevreye yönelik güven duygusunun gelişmesini sağlar. Çocukların davranışsal yetkinlikleri ve bilişsel becerileri artar (Ulutaşdemir, 2007). Oyun, normal gelişim gösteren çocuklar ile özel gereksinimi olan çocukların bir arada bulunabilmeleri için en uygun ortamı sağlayabilmektedir (Sevinç, 2004). Günümüzde, gelişen teknoloji ile birlikte bilgisayar ortamındaki oyunlar günlük hayata girmiştir. Ev ortamında veya farklı sosyal ortamlarda, yalnız veya birlikte oyunun çocukların gelişimine katkısı büyüktür. Zihinsel yetersizliği olan çocuklar zihinsel, kişisel ve sosyal özellikleri açısından diğer bireylerden farklı olsalar da (Agarwal ve Singh, 2012) gelişimsel açıdan oyuna gereksinimleri bulunmaktadır. Tek başına ya da akranlarla oyunlar dışında, yetersizliği olan bireylere yönelik futbol ve voleybol gibi popüler sportif oyunların, onların bedensel, sosyal, vb. gelişimlerinin desteklenmesinde ve yetersizlikleri ile başa çıkmalarında önemli bir etkisi olduğu görülmektedir (Vute, 2009).

Alanyazın incelendiğinde, zihinsel yetersizliği olan ve normal gelişim gösteren çocukların oyun davranışlarının incelenmesi konusundaki çalışmaların sınırlı sayıda olduğu görülmüştür. Bu konuda yurt içinde yapılan çalış- 
malarda, okul öncesi dönem normal gelişen ve down sendromlu çocukların oyun tercihleri ve oyun içindeki iletişimleri (Atik, 1986), nesne ile oyun davranışlarının karşılaştırılması (Özenmiş-Ünsal, 2003), zihinsel yetersizliği olan çocukların kardeşleri ile ilişkileri (Korkmaz, 2008; Yavuz ve Coşkun, 2014), tercih ettikleri oyun köşeleri ve oyun tipleri (Metin, Şahin ve Şanl1, 1999), normal gelişen ilkokul çocuklarının yetersizliği olan akranlarına yönelik tutumları (Çetrez-İşcan, Fazlıoğlu ve Parlak, 2014), zihinsel yetersizliği olan çocukların oyuncak profilleri (Özyürek ve Akça, 2015) gibi konulara değinilmiştir. Yurt dışında yapılan çalışmalarda ise zihinsel yetersizliği olan çocukların dil eğitiminde oyunun kullanılması (Karla ve Banciu, 2013), zihinsel yetersizliği olan çocukların belleği üzerinde ritmik hareketli oyunların etkisi (Javan ve ark., 2012), bilgisayar oyunlarının zihinsel yetersizliği olan çocukların dikkat ve belleği üzerine etkileri (Agarwal ve Singh, 2012) gibi konulara değinilmiştir. Yetersizliği olan çocukların farklı durumlarda ve ortamlardaki oyun davranışlarının karşılaştırmalı olarak incelendiği bir çalışmaya rastlanmamıştır. Bu nedenle bu çalışmada, hafif zihinsel yetersizliği olan bir çocuk tek başına bulunduğu, normal gelişim gösteren ve zihinsel yetersizliği olan akranları ile etkileşim hâlinde iken tercih ettiği oyun davranışlarını değerlendirmek amaçlanmıştır. Çalışmada aşağıdaki sorulara cevap aranmıştır:

1. Hafif düzeyde zihinsel yetersizliği olan çocuğun tek başına iken tercih ettiği oyun davranışları nasıldır?

2. Hafif düzeyde zihinsel yetersizliği olan çocuğun normal gelişim gösteren akranları ile beraberken tercih ettiği oyun davranışları nasıldir?

3. Hafif düzeyde zihinsel yetersizliği olan çocuğun zihinsel yetersizliği olan akranları ile beraberken tercih ettiği oyun davranışları nasıldır?

4. Hafif düzeyde zihinsel yetersizliği olan çocuğun zihinsel yetersizliği olan ve normal gelişim gösteren akranları ile beraberken tercih ettiği oyun davranışları nasıldır?

Çalışmanın, yetersizliğe sâhip çocukların gelişimlerinin desteklenmesinde ve normal akranlarıyla kaynaştırma uygulamalarında oyundan nasıl yararlanılacağı konusunda eğitimcilere ve yapılacak benzer akademik çalışmalara katk1 sağlayacağı öngörülmektedir. 


\section{Yöntem}

\section{Araştırma Modeli}

Çalışmada, nitel araştırma yöntemlerinden bir kişinin davranışı hakkında detaylı bilgi vermeye yönelik vak'a inceleme modeli kullanılmıştır. Nitel araştırmalar, psikolojik ölçümler ve sosyal olaylarla ilgili derinlemesine bilgi sağlarlar (Büyüköztürk, Kılıç-Çakmak, Akgün, Karadeniz ve Demirel, 2010). Olgu hakkındaki bilgileri yansıtan nicel verilerden çok bulguları destekleyici belgeler, katılımcı görüşleri vb kullanılır. Örneklem amaca yönelik olarak seçilir (Merriam, 2013). Vak'a çalışmaları, bireyin ayrıntılı bir şekilde incelenmesi tekniğidir. Sosyal uyum zorlukları olan, özel ilgi ve dikkat isteyen bireyler üzerinde uygulanabilir (Kepçeoğlu, 2004).

Araştırmada, çocukların oyun ortamında sergiledikleri davranışların belirlenmesi amacıyla katılımsız gözlem yönteminden yararlanılmıştır. Gözlem, bireylerin bireysel ya da grup olarak içinde bulunduğu koşullarını ve etkilerini değiştirmeden, onun gözlenebilir bütün davranışları hakkında bilgi toplamaya firsat veren, hem grubun hem de bireyin gelişmesini, gelişimin değişen ya da aksayan yönlerini görmeyi sağlayan sistematik bir bilgi edinme tekniğidir (Kepçeoğlu, 2004; Aydoğan, Özyürek ve Gültekin-Akduman, 2014). Gözlem sürecinde olay ya da kişi olduğu gibi, görüntüler değiştirilmeden, objektif bir şekilde gözlenmektedir (Özgüven, 2007).

\section{Katılımcılar}

Çalışma için etik izin ve resmî izinler alınmıştır. İl Rehberlik ve Araştırma Merkezi (RAM) tarafından "Hafif Zihinsel Yetersizlik" tanısı konmuş ve dördüncü sınıfta kaynaştırmaya alınmış 11 yaşındaki bir erkek çocuğu vak'a olarak ele alınmıştır. Bu çalışmada kendisinden "Ali" kod adı verilerek bahsedilecektir. DSM-IV-TR tanı kriterlerine göre zihinsel yetersizlik; ortalamanın önemli derecede altında entelektüel işlevselik, bireysel olarak uygulanan IQ testinde yaklaşık 70 ya da altında bir IQ olması, iletişim, kendine bakım, ev hayatı, kişilerarası beceriler, toplumun sağladığı olanakları kullanma, kendi kendini yönetip yönlendirme, okulla ilgili işlevsel beceriler, iş, boş zamanlar, sağlık ve güvenlik alanlarından en az ikisinde o sıradaki uyum işlevinde eş zamanlı yetersizliğe sâhip olmaktır (Amerikan Psikiyatri Birliği, 2001). Çalışmaya Ali'nin sınıfındaki normal gelişim gösteren bir kız ve bir erkek, zihinsel yetersizliği olan bir kız bir erkek akranı da dâhil edilmiştir. 


\section{Veri Toplama Araçları}

Verilerin toplanmasında araştırmacılar tarafından geliştirilen gözlem formu kullanılmıştır. Gözlem formunda çocuklar sınıf ortamına geldiğinde tercih ettiği öğrenme merkezi, oynadığı oyun tipi, çocuğun oyunu tek başına sürdürüp sürdürmediği, oyun materyali ya da bulunduğu ortamı arkadaşlarıyla paylaşıp paylaşmadığı, çocuğun tercih ettiği oyun stilleri bölümleri yer almaktadır. Oyun stilleri; çocuğun diğerlerinden bağımsız, kendi kendine, sosyal iletişimde bulunmadan oynadığı izole oyun (Metin, Şahin ve Şanlı, 1999), çocuğun aynı ortamı paylaşmasına rağmen arkadaşlarından çok kendi oyunu ile ilgilendiği paralel oyun (Metin-Aslan, 2013), çocuğun sözel ya da sözel olmayan iletişim davranışları içerisinde diğer çocuklarla birlikte oynadığı beraber oyun, rollerin ve oyunların diğer çocuklarla paylaşılarak işbirliği içerisinde yürütüldüğü kooperatif oyun olarak ele alınmıştır (Sevinç, 2004). Ayrıca çocuğun oyuna ve oyun merkezine ayırdığı toplam süre yer almıştır. Oluşturulan gözlem formu özel eğitim, çocuk gelişimi, okul öncesi eğitim, sosyal hizmet, ölçme ve değerlendirme alanlarından yedi öğretim elemanının görüşüne sunularak kapsam geçerliği sağlanmaya çalışılmıştır. Gözleme dayalı ölçümlerin güvenirliği için, gözlemlerin zamana bağlı olarak tekrarlanabilirliği yönteminden yararlanılmıştır (Balc1, 2005). Çocuklar, farklı zaman dilimlerinde ve farklı ortamlarda gözlenerek gözlem sonuçları kaydedilmiştir. Böylece toplanan verilerin dış güvenirliğinin sağlanması amaçlanmıştır.

\section{Verilerin Toplanması}

Katılımsız gözlem sürecinde; oyun alanının özellikleri ve çeşitli oyuncakları içermesi nedeniyle Ali'nin okuduğu okuldaki anasınıfından istifade edilmiştir. Ali'nin tek başına iken (iki gözlem), zihinsel yetersizliği olan kız (iki gözlem) ve erkek akranı ile birlikte iken (iki gözlem), normal gelişim gösteren kız (iki gözlem) ve erkek akranı ile birlikte iken (iki gözlem), zihinsel yetersizliği olan ve normal gelişim gösteren kız akranları (iki gözlem), zihinsel yetersizliği olan ve normal gelişim gösteren erkek akranları (iki gözlem) ve akranlarının hepsi ile birlikte iken (iki gözlem) sergilediği oyun davranışları araştırmacı tarafından gözlenmiştir. Böylece toplamda 16 gözlem yapılmıştır. Araştırmacı, olaya müdahale etmeyip sınıfın uygun bir yerinde durarak gözlemini yapmıştır. Gözlemler, çocukların oyun süreleri dikkate alınarak oyunlarının bittiğine ilişkin davranışlar gözlenen kadar devam etmiş ve ortalama 15 dakika sürmüştür. Gözlem yapan tek bir araştırmacı 
olduğu için gözden kaçan durumları kontrol altına alabilmek adına, her bir durum iki farklı zaman diliminde gözlenerek güvenirliğin artırılması amaçlanmıştır. Gözlem sonuçları, önceden hazırlanan gözlem formu üzerinde not tutularak kaydedilmiştir.

Gözlem yapılan sınıfin fiziksel yerleşimi şu şekilde betimlenebilir: Sınıfa kapıdan girildiğinde soldan sağa doğru kitapların ve televizyonun yer aldığı bir dolap, blok ve fen merkezleri, öğrenci dolapları yer almaktadır. Sınıfın karşı tarafında, sol köşede ve sınıf penceresinin önünde dramatik oyun merkezi bulunmaktadır. Dramatik oyun merkezinin sağında, çocukların masaları ve öğretmen masası, öğretmen masasının hemen yanında kitap merkezi yer almaktadır. Blok merkezinde legolar, eşleştirme kartları, çeşitli şekillerde ve büyüklükte tahta bloklar, lobutlar, çeşitli büyüklükte oyuncak arabalar, top, balon, yap-bozlar yer almaktadır. Kitap merkezinde çocuklara yönelik resimli öykü kitapları, fen merkezinde küçük hayvan minyatürleri, insan anatomisini gösteren küçük bir heykel, diş yapısını gösteren yapay diş modeli, ağırlık ölçme materyali olarak terazi bulunmaktadır. Dramatik oyun merkezinde minyatür ev eşyaları, tamir seti, sağlık seti, minderler, oyuncak bebekler ve pelüş oyuncaklar yer almaktadır. Çalışmada, her bir gözlem oturumu için aynı düzenin korunmasına özen gösterilmiştir.

\section{Verilerin Analizi}

Nitel araştırmalarda elde edilen veriler, bir durumu derinlemesine inceleyerek açıklayan kavram ve temalara ulaşılmasını gerektiren içerik analizi yöntemi veya derinlemesine analiz gerektirmeyen verilerin işlenmesinde kullanılan betimsel analiz yöntemiyle analiz edilmektedir (Yıldırım ve Şimşek, 2000). Bu çalışmada, gözlem formuna yazılı olarak kaydedilen gözlem sonuçları içerik analizi ile analiz edilmiştir. Elde edilen bilgiler, kodlamalar şeklinde gruplandırılmıştır. Çocukların oyun davranışları ve akran etkileşimleri, tercih edilen oyun alanı ve oyun alanında geçirilen süreler dikkate alınarak temalar oluşturulmuştur. Temalarda, çocukların genel olarak hangi oyun davranışına ne kadar süre ayırdığı veya ne tür oyunlar oynadıkları ele alınmış; fakat oyunun içeriğinin belirli bir amaca uygun olup olmadığı irdelenmemiştir.

\section{Bulgular}

$\mathrm{Bu}$ bölümde, hafif zihinsel yetersizliği olan çocuk tek başına iken, 
normal gelişim gösteren ve zihinsel yetersizliği olan akranlarıyla etkileşim hâlinde iken tercih ettiği oyun davranışları "Tek başına oyun davranışları" "Akranları ile birlikte oyun davranışları" ve "Akran etkileşimi” olmak üzere üç farklı tema hâlinde ele alınarak sunulmuştur.

\section{Tema 1. Tek Başına Oyun Davranışları}

$\mathrm{Bu}$ tema başlı̆g 1 altında, Ali'nin tek başına iken oyun davranışları ele alınmıştır. İlk gözlem esnasında Ali, blok merkezinde vakit geçirmeyi tercih etmiştir. Oyuncak olarak lobut, balon, eşleştirme kartları ve legoları tercih etmiştir. Balon ile oyuna bir dakika, eşleştirme kartları ile oyununa yedi dakika, legolarla kule yapımı oyununa beş dakika ayırmıştır. İkinci gözlemde, balon oyununa sekiz dakika ayırmış ve ilk gözlemden farklı olarak dramatik oyun merkezinde bulunan geometrik şekillerle ilgili eşleştirme oyununa üç dakika ayırmıştır. Ali'nin tek başına oyun oynamaya başladığında mutlu ve heyecanlı olduğu; ama zaman ilerledikçe sıkılmış bir ifadeye büründüğü gözlemlenmiştir.

\section{Tema 2. Akranlarla Birlikte Oyun Davranışları}

$\mathrm{Bu}$ tema başlığı altında, Ali'nin zihinsel yetersizliği olan kız akranı, zihinsel yetersizliği olan erkek akranı, zihinsel yetersizliği olan kız ve erkek akranları, normal gelişim gösteren kız akranı ve normal gelişim gösteren erkek akranı, normal gelişim gösteren kız ve erkek akranları, zihinsel yetersizliğe sâhip ve normal gelişim gösteren kız ve erkek akranları ile birlikte iken tercih ettiği oyun davranışları ele alınmıştır. Ali’nin zihinsel yetersizliğe sâhip akranları ile oyun davranışlarına ilişkin gözlem sonuçlarına ilişkin bulgular Tablo 1'de sunulmuştur.

Tablo 1 incelendiğinde, Ali'nin hafif zihinsel yetersizliği olan kız akranıyla ilk birlikteliğinde, blok merkezinde oynamayı tercih ettiği görülmektedir. Sosyal oyun davranışı olarak birlikte oyun oynama davranış1 görülmüş, iki çocuğun oyuncak tercihi eşleştirme kartları olmuş ve bu oyuna 12 dakika ayırmışlardır. Yapılan ikinci gözlemde ise, çocuklar birinci gözlemden farklı olarak dramatik oyun merkezinden aldıkları doktor muayene materyalleriyle iki dakika oynamışlardır. Bunun dışında sosyal oyun davranışı olarak izole oyun oynayan Ali, fen merkezinde büyüteç ile oynadığı oyuna üç dakika ayırmıştır. 
Tablo 1. Ali'nin Zihinsel Yetersizliğe Sâhip Akranları ile Oyun Davranışları

\begin{tabular}{|c|c|c|c|c|}
\hline $\begin{array}{l}\text { Yetersizliğe } \\
\text { Sâhip } \\
\text { Akran }\end{array}$ & Gözlem & $\begin{array}{l}\text { Tercih Edilen } \\
\text { Oyun Alanı }\end{array}$ & $\begin{array}{l}\text { Sosyal Oyun } \\
\text { Davranışı }\end{array}$ & $\begin{array}{l}\text { Oyun/Oyuncak Tercihi ve } \\
\text { Oyun Süresi }\end{array}$ \\
\hline \multirow[t]{2}{*}{$\mathrm{K}_{1 \mathrm{Z}}$} & 1.gözlem & Blok merkezi & Birlikte oyun & Eşleştirme kartları (12 dk.) \\
\hline & 2.gözlem & $\begin{array}{l}\text { Dramatik oyun } \\
\text { merkezi }\end{array}$ & İzole oyun & $\begin{array}{l}\text { Doktor muayene materyalleri } \\
(2 \mathrm{dk} .)\end{array}$ \\
\hline \multirow[t]{3}{*}{ Erkek } & 1.gözlem & Blok merkezi & Birlikte oyun & Legolar (4 dk.) ve balon ( $2 \mathrm{dk}$.) \\
\hline & 2.gözlem & $\begin{array}{l}\text { Dramatik oyun ve } \\
\text { Blok merkezi }\end{array}$ & Birlikte oyun & Eşleştirme kartları (15 dk.) \\
\hline & & Fen merkezi & İzole oyun & Büyüteç (3 dk.) \\
\hline \multirow{2}{*}{$\begin{array}{l}\text { Kiz ve } \\
\text { erkek }\end{array}$} & 1.gözlem & Blok merkezi & Birlikte oyun & Balon (4 dk.), top (6 dk.) \\
\hline & 2.gözlem & Blok merkezi & Birlikte oyun & Top (1 dk.) \\
\hline
\end{tabular}

Ali, hafif zihinsel yetersizliği olan erkek akranıyla ilk birlikteliğinde, blok merkezinde oynamayı tercih etmiştir. Sosyal oyun davranışı olarak birlikte oyun oynama davranışı görülmüş, iki çocuğun oyuncak tercihi legolar ve balon olmuştur. Çocuklar legolarla oynadıkları oyuna dört dakika, balon oyununa iki dakika ayırmışlardır. Yapılan ikinci gözlemde ise, birinci gözlemden farklı olarak dramatik oyun ve blok merkezinde oynadıkları geometrik şekillerle eşleştirme oyununa 15 dakika ayırmışlardır.

Ali, zihinsel yetersizliği olan kız ve erkek akranlarıla ilk birlikteliğinde oyun merkezi olarak blok merkezini tercih etmiştir. Sosyal oyun davranışı olarak birlikte oyun davranışı gözlemlenmiş̧tir. Ali, kız ve erkek akranlarıyla birlikte balonla dört dakika, topla "ortada sıçan" oyununu altı dakika boyunca oynamışlardır. İkinci gözlemde ise, kız akranı oyuna katılmak istemediği için Ali, erkek akranını tercih etmiş ve onunla oynadığı top oyununa bir dakika ayırmışlardır.

Ali’nin normal gelişim gösteren akranlarıyla oyun davranışlarına ilişkin gözlem sonuçlarını gösterir bulgular Tablo 2'de sunulmuştur.

Tablo 2 incelendiğinde, Ali’nin normal gelişim gösteren kız akranıyla ilk birlikteliğinde blok merkezini tercih ettiği görülmektedir. Sosyal oyun davranışı olarak birlikte oyun oynama davranışı görülmüş ve oyuncak tercihi eşleştirme kartları olmuştur. Eşleştirme kartlarıyla oynadıkları oyuna, sekiz dakika ayırmışlardır. İkinci gözlemde, birlikte oynadıkları bowling oyununa iki dakika, voleybol oyununa beş dakika, futbol oyununa bir dakika ayırmış- 
lardır. Bunun dışında, sosyal oyun davranışı olarak izole oyun davranışı görülmüş ve Ali, dramatik oyun merkezinde pelüş oyuncaklarla bir dakika kendisi oynamıştır.

Tablo 2. Ali'nin Normal Gelişim Gösteren Akranları ile Oyun Davranışları

\begin{tabular}{|c|c|c|c|c|}
\hline $\begin{array}{l}\text { Normal } \\
\text { Gelişim } \\
\text { Gösteren } \\
\text { Akran } \\
\end{array}$ & Gözlem & $\begin{array}{l}\text { Tercih Edilen } \\
\text { Oyun Alanı }\end{array}$ & $\begin{array}{l}\text { Sosyal Oyun } \\
\text { Davranışı }\end{array}$ & $\begin{array}{c}\text { Oyun/Oyuncak Tercihi ve } \\
\text { Oyun Süresi }\end{array}$ \\
\hline \multirow[t]{3}{*}{ Kiz } & 1.gözlem & Blok merkezi & Birlikte oyun & Eşleştirme kartları (8 dk.) \\
\hline & 2.gözlem & Oyun alanı & Birlikte oyun & $\begin{array}{l}\text { Lobutlarla bowling (2 dk.), } \\
\text { Voleybol ( } 5 \mathrm{dk} .) \text {, Futbol (1 dk.) }\end{array}$ \\
\hline & & $\begin{array}{l}\text { Dramatik oyun } \\
\text { merkezi }\end{array}$ & İzole oyun & Peluş oyuncaklar (1 dk.) \\
\hline \multirow[t]{3}{*}{ Erkek } & 1.gözlem & $\begin{array}{l}\text { Blok merkezi ve } \\
\text { dramatik oyun } \\
\text { merkezi }\end{array}$ & Birlikte oyun & $\begin{array}{l}\text { Sayı kutucukları (1 dk.) ve } \\
\text { Lobutlarla bowling ( } 3 \mathrm{dk} .) \\
\text { Geometrik şekiller }(2 \mathrm{dk} .)\end{array}$ \\
\hline & & & Paralel oyun & Top (1 dk.) \\
\hline & 2.gözlem & Blok merkezi & Birlikte oyun & $\begin{array}{l}\text { Direksiyon ile arabacilik oyunu } \\
(1 \mathrm{dk} .) \text {, Basket atma ( } 2 \mathrm{dk} .)\end{array}$ \\
\hline \multirow[t]{2}{*}{$\begin{array}{l}\text { K1z ve } \\
\text { Erkek }\end{array}$} & 1.gözlem & Blok merkezi & $\begin{array}{l}\text { Birlikte oyun } \\
\text { İzole oyun }\end{array}$ & $\begin{array}{l}\text { Trafik işaretleri (4 dk.), Balon (2 } \\
\text { dk.), Top (3 dk.) } \\
\text { Top (1 dk.) }\end{array}$ \\
\hline & 2.gözlem & $\begin{array}{l}\text { Dramatik oyun } \\
\text { merkezi } \\
\text { Blok merkezi } \\
\end{array}$ & Birlikte oyun & $\begin{array}{l}\text { Geometrik şekiller ( } 1 \mathrm{dk} .) \\
\text { Lobutlarla bowling ( } 3 \mathrm{dk} .)\end{array}$ \\
\hline
\end{tabular}

Ali, normal gelişim gösteren erkek akranıyla ilk birlikteliğinde blok ve dramatik oyun merkezini tercih etmiştir. Sosyal oyun davranışı olarak birlikte oyun oynama davranışı ve paralel oyun davranışı da gözlemlenmiştir. Birlikte oynadıklarında blok merkezinden sayı kutucukları ve lobutları tercih etmişlerdir. Sayı kutucuklarına bir dakika ve bowling oyununa üç dakika zaman ayırdıkları gözlemlenmiştir. Dramatik oyun merkezindeki geometrik şekillerle iki dakika oynadıkları, paralel oyun oynama davranışı olarak her ikisinin de topla birer dakika oynadıkları görülmüştür. İkinci gözlemde, blok merkezinden aldıkları direksiyonlarla oynadıkları ve arabacılık oyununa bir dakika, basket atma oyununa iki dakika ayırdıkları görülmüştür.

Ali normal gelişim gösteren kız ve erkek akranıyla ilk birlikteliğinde, blok merkezini tercih etmiştir. Ali'nin sosyal oyun davranışında daha çok erkek akranıyla birlikte oynadığı gözlemlenmiş, trafik işaretlerinin yer aldığ 1 minyatür oyuncaklarla bir dakika oynadıktan sonra izole oyun davranışı 
olarak tek başına bir dakika top oynamıştır. Sonrasında sıkıldığı gözlenen Ali, tekrar erkek akranının yanına gelerek oyuna katılmış ve aynı oyunu birlikte üç dakika daha oynadıkları gözlemlenmiştir. Daha sonra, erkek akranıyla iki dakika boyunca balon oyunu oynamışlardır. Ali, kız ve erkek akranı, birlikte "ortada sıçan” oyununa üç dakika zaman ayırmışlardır. İkinci gözlemde Ali ve erkek akranı dramatik oyun merkezindeki geometrik şekillerle bir dakika, daha sonra blok merkezinde üç dakika bowling oyunu oynamışlardır.

Ali, hafif zihinsel yetersizliği olan ve normal gelişim gösteren kız ve erkek akranlarının bütünüyle beraberken, bütün çocukların katıldığı birlikte oyun oynama davranışı görülmüş ve üç dakika "ortada sıçan" oyunu oynamışlardır. Ali, daha sonra oyun arkadaşı olarak normal gelişim gösteren erkek akranını tercih etmiş, kum torbasıyla oynadıkları oyuna bir dakika ayırmışlardır. Blok merkezinde, kız ve erkek akranıyla resim kartlarını kullanarak üç dakika tabu oyunu oynayan Ali, erkek akranı sıkıldığını belirterek oyundan çıktıktan sonra, kız akranlarıyla aynı oyunu iki dakika daha oynamıştır. İkinci gözlemde birinci gözlemden farklı olarak Ali, normal gelişim gösteren kız akranı ve zihinsel yetersizliği olan erkek akranı ile iki dakika top oynamıştır. Daha sonra Ali aynı oyuna sadece normal gelişim gösteren kız akranı ile devam etmiş ve üç dakika daha oynamışlardır. Normal gelişim gösteren erkek akranının yönlendirmesiyle Ali, normal gelişim gösteren akranları ve zihinsel yetersizliği olan erkek akranı ile dört dakika "ortada sıçan" oyunu oynamışlardır. Zihinsel yetersizliği olan kız akranın ise kendi isteği ile oyuna hiç katılmadığı gözlemlenmiştir.

\section{Tema 3. Akran Etkileşimi}

Bu tema başlığı altında Ali'nin akran etkileşimine yönelik davranışları, tek başına ve akranlarıyla birlikte oyun sürecindeki duygu durumu ele alınmıştır.

Ali'nin tek başına kaldığı ya da arkadaşlarıyla oynamadığı durumlarda sınıfta amaçsızca dolaştığı, oyun kurmakta zorlandığı ve mutsuz bir yüz ifadesine sâhip olduğu gözlenmiştir. Ali'nin yapılan bütün gözlemlerde arkadaşlarıyla oynarken gülümseyen bir yüz ifadesi takındığı, oyunda arkadaş sayısı arttıkça daha fazla eğlendiğini gösteren mimikleri olduğu gözlemlenmiştir. Ali'nin, tüm gözlemlerde birlikte oyunu tercih ettiği görülmüştür. Arkadaşlarıyla sürekli etkileşim hâlinde olmak istemiş ve iletişime geçmiş 
olan Ali, arkadaş tercihinde kız ve erkek ayrımı yapmamış, genel olarak oynamak istediği oyuna göre arkadaşlarının oyunlarına katılmıştır. Yalnızca birlikte oynadıkları oyunlarda, özellikle erkek akranlarının da oyuna katılmasını istemiş, bazı oyunlarda onlar oyundan çıktığında Ali de oyundan çıkmış ya da oyunu erkek akranlarının istediği şekilde düzenlemek için diğer arkadaşlarını ikna etmiştir. Çok eğleniyor göründüğü ve kalabalık arkadaş grubuyla oynadıkları oyunlarda normal gelişim gösteren kız akranı istediğinde, oyun kurallarının değişmesi için diğer arkadaşlarını ikna etmiştir. Zihinsel yetersizliği olan kız akranını oyunlarına sürekli davet etmiş; fakat arkadaşı oyuna katılmak istemediğini belirtince ısrarcı olmamıştır. Ali, normal gelişim gösteren erkek akranın katılmadığı oyunlarda kuralları genellikle kendisi belirlemiş, erkek akranın olduğu oyunlarda onun kurallarına göre oyunu oynamış, onun davranışlarını model almış ve en çok onunla oynamak istemiştir.

\section{Tartışma ve Sonuç}

Hafif zihinsel yetersizliği olan bir çocuğun vak'a olarak ele alındığı bu çalışmada, Ali ismiyle kodlanan zihinsel yetersizliğe sâhip bir çocuğun tek başına iken ve yetersizliği olan akranları ve normal gelişim gösteren akranlarıyla birlikteyken sergilediği oyun davranışları incelenmiştir. Çalışmada Ali'nin tek başına iken oyun davranışları gözlemlendiğinde, genellikle blok merkezi ve bu alanda bulunan oyuncakları tercih ettiği görülmüştür.

Ali'nin zihinsel yetersizliğe sâhip akranlarıyla oyun davranışları gözlemlendiğinde, blok ve dramatik oyun merkezlerinde kız ve erkek arkadaşlarıyla birlikte oyun oynamayı tercih ettiği, bir arkadaşıyla birlikteyken kısa bir süre izole oyun oynadığı görülmüştür. Ali'nin normal gelişim gösteren akranlarıyla oyun davranışları gözlemlendiğinde, çocukların blok ve dramatik oyun merkezi ve sınıf oyun alanını kullandıkları, Ali’nin daha çok birlikte oyun davranışı sergilediği görülmüştür. Tercih söz konusu olduğunda, Ali'nin erkek arkadaşıyla oynamayı tercih ettiği görülmüştür. Arkadaşlarıyla birlikteyken bir-üç dakikalık sürelerde izole oyun davranışı gözlenmiştir. Çocukların, oyun materyali olarak eğitici oyuncaklar ve top oyunlarını, arabacılık oyununu tercih ettikleri gözlenmiştir. Gözlemler esnasında, bütün grubun bildiği bir top oyunu olan "yakan top" olarak da bilinen "ortada sıçan" oyununu oynadıkları gözlenmiştir. 
Alanyazında çalışma bulgularını destekleyen araştırmalar mevcuttur. Yavuzer (2001) kız çocuklarının bebek, model gibi oyuncakları erkek çocuklarının ise tekerlekli oyuncaklar, top, uzaktan kumandalı oyuncakları tercih ettiklerini saptamıştır. Çelebi-Öncü ve Ünlüer (2009) okul öncesi çocukların oyun materyali tercihlerini inceledikleri çalışmalarında, çocukların cinsiyetlerine göre oyun materyallerinin değiştiğini belirlemişlerdir. Metin, Şahin ve Şanlı (1999), 4-9 yaş grubundaki zihinsel yetersizliğe sâhip çocuklarla yaptıkları çalışmada, kız çocukların dramatik oyun merkezi, erkek çocukların blok merkezine âit materyalleri tercih ettiklerini belirlemişlerdir. Atik (1986) 6-9 yaş grubundaki down sendromlu çocuklar üzerinde yaptığı çalışmasında, çocukların en çok paralel oyun oynadıklarını, yaşın artışına paralel olarak birlikte ve kooperatif oyun sıklığında artış olduğunu gözlemlemiştir. İki-üç yaşındaki çocuklar genelde tek başına ve paralel oyunu tercih ederken, dört yaşından sonra bu tercih beraber ve kooperatif oyuna yerini bırakmaktadır (Metin, Şahin ve Şanlı, 1999). Bu bulgular, çalışmanın cinsiyetin oyun ve oyun arkadaşı tercihi ile ilgili bulguyu destekler niteliktedir.

Ali’nin akranları ile etkileşimine yönelik davranışları, tek başına ve akranlarıyla birlikte oyun sürecindeki duygu durumu incelendiğinde; tek başına kaldığı ya da arkadaşlarıyla oynamadığı durumlarda sınıfta amaçsızca dolaştı̆̆1, oyun kurmakta zorlandığı ve mutlu olmadığı, arkadaşlarıyla oynarken mutlu olduğu ve oyunda arkadaş sayısı arttıkça daha fazla eğlendiği görülmüştür. Ali'nin genellikle akranlarıyla birlikte oyun oynamayı tercih ettiği, akranlarıyla sürekli etkileşim hâlinde olmak istediği ve iletişim içerisinde olduğu, akranları arasında kız veya erkek ayrımı yapmadığı, arkadaşlarının oyununa katıldığı ve oyun dışındaki arkadaşını oyuna davet ettiği, oyunun kurallarına uyduğu görülmüştür.

Akranlar arası etkileşim, çocukların başta sosyal gelişimleri yanında dil gelişimi, duygusal gelişim ve kavram öğrenimini içeren zihinsel gelişimi de destekleyecektir. Bu etkileşimin en fazla sağlanabileceği ortam ise oyun ortamıdır. Normal gelişim gösteren ve özel gereksinime ihtiyaç duyan kaynaştırma öğrencileri üzerinde yapılan çalışmalarda kaynaştırma öğrencilerinin problem davranış sergiledikleri, sosyal becerilerin az olduğu, arkadaşlık ilişkilerinde zorladıkları ve akranları tarafından dışlandıkları sonuçlarına ulaşılmıştır (Çulhaoğlu-İmrak, 2009; Güleryüz, 2009; Orhan, 2010; Sucuoğlu ve Özokçu, 2005). Çetrez-Işcan, Fazlığlu ve Parlak (2014), ilkokula devam 
eden normal gelişim gösteren çocukların yetersizliği olan akranlarına yönelik tutumlarını incelediği çalışmalarında, sınıflarında kaynaştırma öğrencisi olan çocukların, sınıflarında kaynaştırma öğrencisi olmayan çocuklara göre daha olumsuz bir tutum içinde oldukları sonucuna ulaşmışlardır. Ayral ve arkadaşları (2014) normal gelişim gösteren öğrencilerin özel gereksinimli öğrencilere bakışını etkileyen etkenleri inceledikleri çalışmada, özel gereksinimli öğrencilerin, normal gelişim gösteren akranları arasındaki sosyal kabul düzeylerinin orta düzeye yakın olduğu sonucuna ulaşmışlardır. Gülsün-Kaya (2007) zihinsel yetersizliğe sâhip kaynaştırma öğrencilerinin normal öğrenciler üzerindeki etkilerini saptanmak amacıyla yaptığı çalışmasında, normal öğrencilerin kaynaştırma öğrencilerinin oyunlarına ayak uydurabildiklerini, kurallara uyduklarını, görgü kurallarına uyduklarını, fiziksel ya da ruhsal yönden olumsuz etkilenmediklerini belirlemiştir.

Yetersizliği olan çocuklar, eğitim sürecinde onlara sunulan oyun firsatları sayesinde başkalarıyla etkileşime girmeyi, arkadaşlık bağlarını geliştirmeyi, birlikte çalışmayı öğrenmektedirler. Ayrıca oyun ortamında, çocuklara belirli kavram ve zihinsel becerilerin kazandırılması da mümkün olmaktadır (Sevinç, 2004). Alanyazın ve araştırma bulguları 1şığında, zihinsel yetersizliğe sâhip olan çocukların da normal gelişim gösteren bütün çocuklar gibi oyun oynamaya ve akranlarıyla etkileşime girmeye ihtiyaç duydukları söylenebilir. Yetersizliğe sâhip çocuklara yaşları ne olursa olsun kendi akranlarıyla birlikte olmayı sağlayacak oyun ortamı sunulması, gelişimlerini desteklemek için önemli bir firsat sunacaktır. Ayrıca sunulacak bu ortamın, normal gelişim gösteren çocuklara da olumlu gelişimsel katkılar sağlayacağı söylenebilir.

Bu çalışmada, tek bir vak'a incelenmiş ve yalnızca zihinsel yetersizliğe sâhip bir çocuğun tek başına ve akranlarıyla oyun davranışı gözlenerek analiz edilmiştir. Farklı yetersizlik alanlarından daha fazla sayıda çocukla benzer bir çalışma yapılması önerilebilir. Ayrıca gözlem dışında anne-baba, kardeş, öğretmen gibi çocukları yakından tanıyan kişilerden edinilen bilgilerle verilerin desteklenmesi, daha güvenilir sonuçlar sunabilir. Çocukların akran etkileşimleri, deney düzeneği şeklinde sunulan bir sınıf ortamı yerine açık oyun alanlarında, sınıfında yer alan bütün öğrencilerin bulunduğu ortamlarda incelenebilir. 


\section{Kaynakça}

Adıgüzel, Ö. (2013). Eğitimde yaratıcı drama (4. baskı). Ankara: Pegem Akademi.

Agarwal, A. ve Singh, Y. (2012). Computer gaming for children with mental retardation. Spectrum: A Journal of Multidisciplinary Research, 1(8), 31-26.

Amerikan Psikiyatri Birliği. (2001). Ruhsal bozuklukların tanısal ve sayımsal el kitabı (DSM-IV) (4. bask1). (E. Köroğlu, Çev. Ed.). Ankara: Hekimler Yayın Birliği. (Orijinal çalışma basım tarihi 2000)

Arı, R. (2006). Gelişim ve öğrenme (3. baskı). Ankara: Nobel Yayıncılık.

Atik, B. (1986). Okul öncesi çă̆daki normal gelişim gösteren çocuklar ile down sendromlu çocukların tercih ettikleri oyun tiplerinin ve oyun içindeki sosyal iletişim davranışlarının incelenmesi. Yayımlanmamış yüksek lisans tezi, Hacettepe Üniversitesi Sağl1k Bilimleri Enstitüsü.

Aydın, B. (2004). Çocuk ve ergen psikolojisi (2. baskı). İstanbul: Atlas Yayın Dağıtım Ltd.

Aydın, G. (2012). Çocuk oyunları el kitabı oynuyorum eğleniyorum. (2. bask1). Ankara: Erten Basim.

Aydoğan, Y., Özyürek, A. ve Gültekin-Akduman, G. (2014). Öğrenme ve ögretme teknikleri. Ankara: Vize Yayıncılık.

Ayral, M., Özcan, Ş., Can, R., Ünlü, A., Bedel, H., Şengün, G., Demirhan, Ş. ve Çağlar, K. (2014). Normal gelişim gösteren öğrencilerin özel gereksinimli öğrencilere bakışını etkileyen etkenler. Abant İzzet Baysal Üniversitesi Eğitim Fakültesi Dergisi, 15 (Özel Sayı), 218-230.

Balc1, A. (2005). Sosyal bilimlerde araştırma. Yöntem, teknik ve ilkeler. Ankara: Pegem Akademi Yayınları. 
Brodin, J. (1999). Play in children with severe multiple disabilities: play with toys-a review, international journal of disability. Development and Education, 46(1), 25-34.

Büyüköztürk, Ş., Kılıç-Çakmak, E., Akgün, Ö. E., Karadeniz, Ş. ve Demirel, F. (2010). Bilimsel araştırma yöntemleri (6. baskı). Ankara: Pegem Akademi.

Çankırıl1, A. (2010). Annem ve babamla oynuyorum öğreniyorum (2. bask1). İstanbul: Zafer Yayınları.

Çeçen, R. (2007). Bilişsel gelişim ve dil gelişimi. M. E. Deniz, (Ed.), Eğitim psikolojisi içinde (79-130). Ankara: Maya Akademi.

Çelebi-Öncü, E. ve Özbay, E. (2006). Okul öncesi çocuklar için oyun (2. bask1). Ankara: Kök Yayıncılık.

Çelebi-Öncü, E. ve Ünlüer, E. (2009). Okul öncesi çocukların oyun materyali tercihlerinin incelenmesi. Uluslararası Katılımlı II. Çocuk Gelişimi ve Ĕ̈itimi Kongresi (Să̆llk, Gelişim ve Ĕgitimde Çocuk) Bildiri Kita$b l$ içinde (569-572). Ankara: Hacettepe Üniversitesi.

Çetrez-İşcan, G., Fazlıoğlu, Y. ve Parlak, C. (2014). İlkokula devam eden normal gelişim gösteren çocukların yetersizliği olan akranlarına yönelik tutumlarının incelenmesi. Abant İzzet Baysal Üniversitesi Eğitim Fakültesi Dergisi, 15 (Özel Sayı), 128-138.

Çulhaoğlu-İmrak, H. (2009). Okul öncesi dönemde kaynaştırma eğitimine ilişkin ögretmen ve ebeveyn tutumlart ile kaynaştırma eğitimi uygulanan sinıflarda akran ilişkilerinin incelenmesi. Yayımlanmamış yüksek lisans tezi, Çukurova Üniversitesi Sosyal Bilimler Enstitüsü.

Fox, J. E. ve Schirrmacher, R. (2014). Çocuklarda sanat ve yaratıcılı̆̆ın gelişimi (7. baskı). (N. Aral ve G. Duman, Çev.). Ankara: Nobel Yayıncılık. (Orijinal çalışma basım tarihi 2012)

Gülay, H. ve Akman, B. (2009). Okul öncesi dönemde sosyal beceriler. Ankara: Pegem Akademi. 
Güleryüz, Ş. O. (2009). Kaynaştırma eğitimine devam eden engelli ögrencilerin akranları ile iliş̧kilerinde karşılaştıkları sorunların değerlendirilmesi. Yayımlanmamış yüksek lisans tezi, Selçuk Üniversitesi Sosyal Bilimler Enstitüsü.

Gülsün-Kaya, G. (2007). Zekâ engelli kaynaştırma öğrencilerinin normal ögrenciler üzerindeki etkilerinin saptanması. Yayımlanmamış yüksek lisans tezi, Beykent Üniversitesi Sosyal Bilimler Enstitüsü.

Hirsh, R. A. (2004). Early childhood curriculum: Incorporating multiple intelligences, developmentally appropriate practice, and play. Boston: Pearson.

Javan, A. T. P., Abedi, A., Nattaj, F. H. ve Dehghani, M. (2012). The effectiveness of rhythmic movement games on memory in children with mental retardation. Journal of Life Science and Biomedicine, 2(4), 161-166.

Karla, P. ve Banciu, V. (2013). Game using in the language education activities of children with mild and moderate mental disabilities, International Journal of Information and Education Technology, 3(3), 393-396.

Kepçeoğlu, M. (2004). Psikolojik danışma ve rehberlik. İstanbul: Alkım Yayınevi.

Korkmaz, A. (2008). Özel eğitim alan zihinsel engelli çocukların kardeşleri ile ilişsilerinin değerlendirilmesi. Yayımlanmamış yüksek lisans tezi, Genelkurmay Başkanlığı Gülhane Askeri Tıp Akademisi Sağlık Bilimleri Enstitüsü.

Merriam, S. B. (2013). Nitel araştırma, desen ve uygulama için bir rehber (S. Turan, Çev. Ed.). Ankara: Nobel Yayınları. (Orijinal çalışma basım tarihi 2012)

Metin-Aslan, Ö. (2013). Anaokuluna devam eden çocuklarının oyun davranışları ve oyunlarında ortaya çıkan zorbalık davranışlarının incelen- 
mesi. Yayımlanmamış doktora tezi, Hacettepe Üniversitesi Sosyal Bilimler Enstitüsü.

Metin, N., Şahin, S. ve Şanlı, E. (1999). Okul öncesi düzeyde ve dört-dokuz yaş grubundaki zihinsel engelli çocukların tercih ettikleri oyun köşeleri ve oynadıkları oyun tiplerinin incelenmesi. Özel Eğitim Dergisi, 2(3), 14-24.

Milli Eğitim Bakanlığı. (2009). Çocuk gelişimi ve eğitimi oyun etkinliği-I. Ankara: Milli Eğitim Bakanlığı Yayınları.

Milli Eğitim Bakanlığı. (2011). Okullarımızda neden niçin kaynaştırma (2.bask1). Ankara: Milli Eğitim Bakanlığı Yayınları.

Orhan, M. (2010). Okul öncesi kaynaştırma ögrencileriyle normal gelişim gösteren ögrencilerin sosyal beceri ve problem davranışlarının düzeyi ile ögrretmenlerin kaynaştırmaya ilişkin görüşlerinin incelenmesi. Yayımlanmamış yüksek lisans tezi, Anadolu Üniversitesi Eğitim Bilimleri Enstitüsü.

Ormanlığlu-Uluğ, M. ve Karadeniz, G. (2011). Okul öncesi çocuk ve... Ankara: Nobel Yayıncılık.

Özenmiş-Ünsal, P. (2003). Zihinsel engelli olan ve olmayan çocukların nesne ile oyun davranışlarının karşılaştırmalı olarak incelenmesi, Ankara Üniversitesi Eğitim Bilimleri Fakültesi Özel Eğitim Dergisi, 4(1), 46-55.

Özgüven, İ. E. (2007). Bireyi tanıma teknikleri (7. baskı). Ankara: Pdrem Yayınları.

Özyürek, A. ve Akça, A. (2015). Zihinsel yetersizliği olan çocukların oyuncak profillerinin incelenmesi, Bartın Üniversitesi Eğitim Fakültesi Dergisi, 4(2), 516-529.

Pellegrini, A. D. (2009). Research and policy on children's play. Child Development Perspectives, 3(2), 131-136. 
Sevinç, M. (2004). Erken çocukluk gelişimi ve eğitiminde oyun. İstanbul: Morpa Yayınları.

Sucuoğlu, B. ve Özokçu, O. (2005). Kaynaştırma öğrencilerinin sosyal becerilerinin değerlendirilmesi. Ankara Üniversitesi Eğitim Bilimleri Fakültesi Özel Eğitim Dergisi, 6(1), 41-57.

Swith, J. T. (2013). Erken çocukluk döneminde gelişim (5. bask1). (B. Akman, Çev. ed.). Ankara: Nobel Yayıncılık. (Orijinal çalışma basım tarihi 2010)

Özel Eğitim Hizmetleri Yönetmeliği. (2006). T. C. Resmi Gazete, 26184, 31 Mayis 2006.

Ulutaşdemir, N. (2007). Engelli çocuklarda iletişim ve oyunun önemi. Fırat Sağllk Hizmetleri Dergisi, 2(5), 36-51.

Veer, R. (1996). Vygotsky and Piaget: A collective monologue. Human Development, 39, 237-242.

Vute, R. (2009). Teaching and coaching volleyball for the disabled: foundation course handbook, (2. bask1). Ljubljana: Faculty of Education.

Yavuz, M. ve Coşkun, İ. (2014). Normal gelişim gösteren bireyin zihinsel engelli kardeşi ile vakit geçirme durumu. International Periodical For The Languages, Literature And History of Turkish or Turkic, 9(8), 295-313.

Yavuzer, H. (2001). Çocuk psikolojisi (25. baskı). İstanbul: Remzi Kitabevi.

Yıldırım, A. ve Şimşek, H. (2000). Sosyal bilimlerde nitel araştırma yöntemleri (2. baskı). Ankara: Seçkin Yayıncılık.

$\mathrm{Xu}$, Y. (2010). Children's social play sequence: parten's classic theory revisited. Early Child Development and Care. 180(4), 489-498. 